\title{
Selling Queensland: Richard Daintree as Agent-General for Emigration, 1872-1876
}

Richard Daintree is mainly remembered as a talented geological surveyor and pioneer photographer in Queensland in the 1860s, and by the WorldHeritage site named after him - the Daintree Rainforest. ${ }^{1} \mathrm{He}$ is less known for his significant work in the period $1872-6$ as the London-based AgentGeneral for Emigration for Queensland, which is the focus of this article. The English-born Daintree arrived in the colony in 1864 and initially worked in farming in northern Queensland. Between 1868 and 1870 he led a government-sponsored geological survey of northern Queensland and undertook field photography by using a wetplate process. ${ }^{2}$ In 1871 he was selected by premier Arthur Hunter Palmer and the Queensland government to present his geological specimens and photographs as a central part of Queensland's display at the Exhibition of Art and Industry in South Kensington, London, a follow-up to the Great Exhibition of 1851. Daintree's success in making his display a highlight of the exhibition helped him gain the position of Agent-General for Emigration after the previous incumbent, Archibald Archer, resigned over a conflict of interest between the government's policies and his support for the Central Queensland separation movement. ${ }^{3}$

The Agent-General for Emigration, a position established in 1860, was a senior civil service appointment made by the Queensland government. The appointee, based at the Queensland Government Emigration Office, London, received a salary of $f 1,000$, then the highest in the colony's public service, and was responsible for activities vital to the demographic and economic growth of Queensland. His particular function was to oversee immigration and the purchase of goods for Queensland's government, to assist with raising finance from Britain, and to secure arrangements with shipping firms for emigrants. By the 1880s the AgentGeneral undertook a wider range of duties, including liaison with the Colonial Office, and was 'regarded as a cross between an ambassador, a minister and a public servant.' ${ }^{4}$ The Agent-General was the main professional appointed to secure British and Irish emigrants to settle in Queensland. He was answerable to the colony's Premier and Colonial Secretary, often the same person, based in Brisbane. ${ }^{5}$

Daintree became Agent-General for Emigration on 15 April 1872 when the Immigration Act of 1869 was in force. Within four months, this was superseded by the Immigration Act of 1872, which attempted to save money and increase emigration from the British Isles. To cover the government's costs, those arriving in Queensland under assisted packages were now to undertake that they would repay the balance of their passage money of $f 16$ after one year. This removed the lack of inducement for immigrants to fulfil their obligations under the 1869 Act, which included no such stipulation. The 1872 Act provided offers of land to 
those who had paid their own shipping passages to Queensland. Immigrants could make conditional purchases of land for which they were paying rent instalments or homestead selections under the Crown Lands Act of $1868 .^{6}$

While Daintree was Agent-General in the period 1872-6 Queensland's population increased more through net migration than natural increase. ${ }^{7}$ The number of British and Irish immigrants in those years (totalling 27,541 persons) increased significantly from the level attained in the second half of the 1860s. ${ }^{8}$ The Queensland economy, hit by a financial crisis in 18667 , showed signs of economic recovery by 1871-2, and then entered a short boom in the period 1872-5.9 In the first half of the 1870s, Queensland offered significant 'pull' factors to immigrants such as stable labour conditions, mineral discoveries, positive company dividends and burgeoning public infrastructure. The 'push' factors from the British Isles in this period consisted of unfavourable economic conditions in Britain, a fall in agricultural incomes and the availability of impoverished rural workers seeking emigration opportunities. ${ }^{10}$

Emigration from the British Isles to colonial Queensland was critically affected by the abilities and actions of the Agent-Generals, who concentrated their working activities on emigrant recruitment. They liaised with the Colonial Secretary of Queensland over immigration policy. Incumbents were expected to travel throughout the British Isles to facilitate their recruitment activities, and to liaise with agents, sub-agents and shipping firms. ${ }^{11}$ They operated in a competitive market for emigrants, as alternative destinations - other Australian colonies, Canada, the United States, New Zealand - also actively sought settlers from the United Kingdom. Each Agent-General brought to the position different methods of working, with mixed results.

Studies are available of the work of the first Agent-General, Henry Jordan (1861-6), and of his successor John Douglas (1869-71). Jordan was an industrious and indefatigable lecturer whereas Douglas had refused to lecture on the basis (he claimed) that he was not appointed to do so. Jordan and Douglas both had political disagreements with Queensland's colonial government that ultimately were not surmounted. Jordan was the most successful of the two in making suitable passenger arrangements with shipping firms. ${ }^{12}$ Compared with Jordan and Douglas as AgentsGeneral, Daintree's tenure of the position has received some attention but this article provides the first comprehensive study of the success with which he carried out emigration recruitment in the British Isles. ${ }^{13}$ The distribution of literature to sell Queensland and public lectures throughout the British Isles were necessary to publicise what the colony could offer to settlers. Links with shipping firms were required to secure regular services for passengers. Emigrant recruitment needed close attention to the ages and occupations of potential settlers. An efficient operation of 
Queensland's Government Emigration Office would support these initiatives. These facets of the Agent-General's role were bound up with the political direction of immigration from Brisbane and the practicalities of organising it 10,000 miles away in London.

\section{Emigration publicity}

As Agent-General for Emigration, Daintree's photographic knowledge and experience of Queensland's mineral resources helped sell the colony to prospective immigrants. No previous Agent-General had photographic skills or such geological knowledge. Daintree conjoined these interests to promote emigration to Queensland. ${ }^{14}$ He displayed his coloured photographs and mineral samples at the International Exhibition of Art and Industry at South Kensington in 1872. Daintree prepared a catalogue for the opening day of the exhibition on 1 May 1872. ${ }^{15}$ The Colonial Secretary encouraged Daintree in these initiatives. ${ }^{16}$

Daintree's displays concentrated on Queensland's geological deposits because he regarded the colony's future as closely connected to the exploitation of mineral resources, which he expected to attract British capital investment. ${ }^{17}$ These artefacts were situated in a timber pavilion with roof lights in an eastern annexe of the building. Daintree arranged for this to be a permanent annexe representing Queensland. ${ }^{18}$ The following items were positioned on the exhibition's walls: representative photographs of the physical character of Queensland; samples of rocks, soils and products; a coloured map of the colony; statistics on the price at which land could be obtained by ordinary selection; the present market price of the colony's main staples; and a model of an emigrant ship placed in a prominent position, with an outline of Queensland's emigration schemes draped over the model. Daintree visited the exhibition daily to answer questions and give lectures. He was usually there for four hours a day. ${ }^{19}$ In 1873 Daintree augmented the displayed specimens to include tin and gold as well as samples of sugar and timber from Queensland. ${ }^{20}$

Daintree obtained further photographic negatives of towns and industry in Queensland. These were enlarged by an autotype process and hand coloured in oils. The pictures were appreciated by reporters as realistic and well-produced images of Queensland's potential for immigrants. ${ }^{21}$ Visitors to the exhibition admired the photography, which was a new medium for propaganda. ${ }^{22}$ Daintree, who enjoyed his publicity work, claimed there was 'no better or cheaper method for publicising Queensland.'23 That seems a fair comment, but it should be noted that the photographs presented the colony's scenery, geology and industry rather than people. ${ }^{24}$

Daintree also helped to sell Queensland through printed literature and lecturing. He published handbills, placed advertisements in newspapers, and compiled a book explaining the advantages of Queensland to 
investors and emigrants. The book included sections on living costs, immigrant opportunities, types of transport and industry, illustrated with Daintree's photographs. ${ }^{25}$ Daintree claimed in his book, clearly hyperbolically, that in Queensland 'pauperism is unknown. ${ }^{26}$ Newspaper advertisements placed by the Queensland Government Emigration Office drew attention to free shipping passages for agricultural labourers and female domestic servants and assisted passages for mechanics and other eligible persons at lower rates than the cost of passage to Canada or the United States. ${ }^{27}$ The advertisements offered a forty-acre land order for adults paying their own passage (an important aspect of immigration policy explained later). ${ }^{28}$ Remuneration levels for particular occupations were often included, with one notice claiming wages were about double the English rates. ${ }^{29}$ Daintree answered questions about Queensland's wage and employment levels in newspaper columns, and compared the availability of work in the open air all-year-round with climatic conditions in Canada. ${ }^{30}$ He oversaw the production of an illustrated emigration guide, which was available for sale at the South Kensington exhibition. ${ }^{31}$

Daintree deployed several other promotional mechanisms. Letters received from Queensland were printed in pamphlet form and widely circulated. Communications about emigration to the colony were placed in public journals. Information was publicised at the Queensland Annexe, South Kensington, which mercantile and scientific men praised for its comprehensive and instructive contents. ${ }^{32}$ The official printed list of wages for Queensland for the labouring and artisan classes was made available at the Queensland Government Emigration Office. ${ }^{33}$ Posters distributed to full-paying passengers included details about land orders as a prominent feature. ${ }^{34}$ Lying behind these various types of information for potential emigrants was the Queensland government's desire to recruit a healthy stream of settlers capable of working on and improving agricultural land. The progress of a thinly populated colony, it was believed, was co-equal with the volume, continuity, and adaptability of the immigration. ${ }^{35}$ Daintree considered that 'the future progress of the Colony must much depend on the class of people it is now importing. ${ }^{36}$

These activities indicate that Daintree deployed varied, sometimes imaginative, methods for selling Queensland as an emigration destination. It was not so easy, however, to replicate these initiatives outside London: promotional activities for emigration to Queensland were more problematic in rural districts. Spreading information to agricultural labourers was a difficult task, a newspaper being a rare sight in most country villages. Moreover, as Daintree put it, the 'literature in the shape of hand-books \&c distributed among an agricultural population falls on very stony ground. Letters from friends in the colony are by far the most efficacious in arousing attention, and I should certainly urge all those Agricultural Labourers in the Colony who have benefited by Emigration to send home letters to their friends, advising them to follow in their 
footsteps. ${ }^{37}$ This comment points to the significance of chain migration through writing letters home to relatives and friends. It also implies that agricultural labourers rarely travelled to London and would therefore not be exposed to promotional emigration propaganda displayed there. Queensland's politicians placed great emphasis on immigrants supporting themselves on the colony's vast land acreage, and so a means of spreading the spirit of emigration to agricultural workers was needed.

\section{Public recruitment lectures and agents}

Queensland's government instructed Daintree to provide public lectures to promote emigration from the British Isles to the colony, with an emphasis on engagements in rural areas that would stimulate recruitment from agricultural workers. Daintree conscientiously followed this instruction. Aided by his natural speaking ability and sympathy with farm labourers because of his own agricultural background, he provided lectures in many different locations. ${ }^{38}$ In July 1872 , only three months after arriving in London, he arranged for a lecture tour through Dorset, Devon and Cornwall 'to beat up emigrants, the high price of wages $\&$ abundance of work in England requiring extra attention to keep up the supply we require. ${ }^{39}$ After appearing at numerous venues, Daintree concluded that moving 'from village to village lecturing and meetings on the open commons are practically the only lectures of much service, as far as obtaining suitable emigrants is concerned...lecturing in large towns is so much time thrown away. ${ }^{40}$

Besides lecturing, Daintree attended meetings of the recently formed National Agricultural Labourers' Union in order to secure the cooperation of their branch secretaries in his emigration recruitment work. ${ }^{41}$ This union was pledged to support emigration as a means of bettering conditions at home. ${ }^{42}$ It had emerged in the early 1870s, along with others in central and southern England, to promote emigration as a solution for rural labour surpluses. ${ }^{43}$ Daintree also selected emigrants himself during his visits to agricultural districts. ${ }^{44}$

Daintree's lecture in the Town Hall, Truro, Cornwall on 24 September 1872 addressed the topics he invariably covered in his recruitment activities. He explained the advantages offered by Queensland as an emigration destination by starting with a description of the extent of the colony and the nature of its climate. He touched upon its revenue, and by using large maps clearly pointed out to the audience the physical characteristics of the colony and its general adaptability for settlement. After explaining Queensland's various industries, Daintree concluded by stating that the colony possessed great attractions both for labour and capital and that emigrants and their families would benefit materially from emigrating there. A large audience of farm labourers, miners and domestic servants, the classes for whose benefit the lecture was particularly designed, greeted the lecture favourably. ${ }^{45}$ 
To assist with lecturing Daintree appointed James Bonwick, who had resided in Australia for many years. ${ }^{46} \mathrm{He}$ was sent into country districts, and was credited with achieving success in promoting rural emigration. ${ }^{47}$ Thus, for instance, in June 1874 Bonwick lectured in Norfolk and Lincolnshire in association with a smaller trade union, the Amalgamated Labour League of Lincoln and neighbouring counties, whose members were more numerous in those counties than those of the National Agricultural Labourers' Union, which supported impoverished workers wishing to emigrate. ${ }^{48}$ This was followed up with daily lectures in July throughout Norfolk and Suffolk. ${ }^{49}$ The Colonial Secretary, however, disapproved of this appointment because there was no evidence that Bonwick had any personal knowledge of Queensland. The Queensland government wanted to terminate the appointment immediately. ${ }^{50}$ Unhappy with this decision, Daintree defended Bonwick: 'Mr Bonwick, who was for some time in Queensland, has a thorough knowledge of the Australian colonies generally, is a fluent speaker, a fair writer for the press, and is devoted to the object he has been engaged on for Queensland; and his services have been much appreciated by our agents. ${ }^{51}$

In late 1874 Queensland's government, now led by premier Arthur Macalister, decided Daintree had too great a burden lecturing in various parts of the British Isles considering there were numerous other areas in which his work was required as Agent-General. The government became concerned that the attractions of Queensland as a field for emigration were diminishing. ${ }^{52}$ It therefore supported the recruitment of emigrants in the United Kingdom by providing one sub-agent and lecturer for Ireland and another one for Scotland. Daintree himself was to concentrate his lecturing in future on England alone. These additional appointments and the new geographical demarcation of duties were intended to boost the number of full-paying emigrants to Queensland to save expenditure on emigrants receiving free passages. ${ }^{53}$ Queensland's government placed $£ 30,000$ at Daintree's disposal to facilitate this process. ${ }^{54}$ Daintree agreed to support this drive to increase the number of full-paying passengers by supporting lecturing by the new appointees. ${ }^{55}$

The two men appointed as sub-agents for Ireland and Scotland - Edward O'Donnell MacDevitt and George Wight - were allocated annual salaries of $f 500 .{ }^{56}$ Both appointees had made their professional mark in Queensland. MacDevitt was an Irish-born Roman Catholic barrister who had had worked on the North Australian newspaper, and had served in Queensland's legislative assembly and as attorney-general for the colony. ${ }^{57}$ Wight was a Scottish Presbyterian minister and journalist who had lived in Queensland in the $1860 \mathrm{~s} .{ }^{58} \mathrm{He}$ was a permanent member of Queensland's civil service; therefore no time limit was placed upon his appointment as a sub-agent. The case was different with MacDevitt: the duration of his appointment 
was only intended to be for twelve months, and it was made clear that his salary and appointment would then cease. ${ }^{59}$

Daintree liaised with various agents, including MacDevitt and Wight, in order to help with recruiting emigrants in different parts of rural Britain. ${ }^{60}$ He dealt regularly with agents and arranged for fees to be paid to them for their services. These agents corresponded directly with the Queensland Government Emigration Office with regard to free and assisted emigrants, but no correspondence was entered into with them concerning full-payers. Agents received 7s. $6 \mathrm{~d}$. per adult for free emigrants other than domestic servants, for whom they received 12s. ${ }^{61}$

Daintree pledged his support for these appointments but suggested to the Colonial Secretary that, instead of hiring additional lecturers, the recruitment of more full-paying passengers would be better assisted by money spent on annual revised versions of the colony's official handbook. This information should include balance sheets from successful colonists or cooperative associations and the expected returns for investment of capital in agricultural, pastoral and mining pursuits in Queensland. ${ }^{62}$ Daintree's recommendation reflected a sense that the impact of lecturing was possibly an overrated means of recruitment. Even when lectures were well received by audiences and the local press, they were not guaranteed in themselves to stimulate the decision to emigrate.

Lecturing did not always have an immediate effect. Thus, for instance, Daintree found it necessary to engage agents for several months in the Scottish Highlands before achieving results because great persuasion was needed to convince cautious Scots people to emigrate from their homeland. ${ }^{63}$ Wight distributed in Scotland 50,000 copies of his pamphlet, Queensland, the Colony for Working Men. ${ }^{64}$ He confirmed Daintree's experience that lecturing rarely led to immediate results. After lecturing in Ayr, Jedburgh, Coldstream and Kelso, he concluded that people decided every half-year or once a year (often fitting in with agricultural hiring arrangements) whether to emigrate. ${ }^{65}$

Wight was assiduous and industrious. In the year after April 1875 he lectured sixty-seven times in sixteen counties, covering a broad swathe of Scotland from Ayr to Caithness and from Aberdeen to Berwick-uponTweed. His lectures concentrated on three main themes in relation to emigration to Queensland: climate, resources and production. Wight was aided by local agents in Scotland and by the presence at some of his lectures of people who had lived in Queensland. ${ }^{66}$ Aiming his lectures at hardworking agricultural workers, he provided a discursive appraisal of the ways in which a permanent move to Queensland would help emigrants and their families achieve a respectable social and economic position. ${ }^{67}$

MacDevitt lectured in Ireland during 1875, also emphasising Queensland as a colony for the working man. He spoke about the climate, resources 
and employment opportunities in the colony, and drew large audiences in Londonderry, Carlow and elsewhere. ${ }^{68}$ Compared with Wight's positive reception in Scotland, however, MacDevitt's presentations in Ireland backfired owing to sectarianism. He allowed the spirit of religious antagonism to infiltrate his lectures, which unfortunately led to 'a very severe check' to Irish emigration. 'The Orange Press took up the matter in a very bitter spirit,' Daintree reported to the Colonial Secretary, 'and many of their newspapers now attack emigration to any colony, on every convenient occasion. ${ }^{69}$

Apart from Scotland and Ireland, Daintree needed additional help in England because of competition for recruiting emigrants by Canada, New Zealand and South Australia. To ensure continuous lecturing in English agricultural districts, at the end of 1875 Daintree appointed Philip Henry Nind to this role and put him in charge of local agents used by Queensland's government in England. Nind was paid $f 500$ per year, with f20 per month for travelling expenses. The initial term of employment was for six months, with the option for renewal for a similar period on the same terms. ${ }^{70}$ Nind lectured in Wiltshire villages where he concluded that 'there is not the same eagerness which used to be shown amongst the labouring classes to emigrate, and a very determined opposition exists among the farmers and clergy to persons leaving the country.' In March 1876 he reported that agricultural wages had risen considerably in the past year in Oxfordshire, Berkshire, Wiltshire and Buckinghamshire, and this militated against recruitment of potential emigrants to Queensland. ${ }^{71}$

\section{The type of emigrants recruited}

Queensland's government wanted to promote immigration following the colony's financial crisis of the mid-1860s by recruiting farm labourers and skilled workers. There was a desire, evident from the colony's beginnings, to avoid pauper immigrants or large families that would burden Queensland's finances. The Immigration Act of 1872 confirmed that land orders issued to immigrants would continue. This was a system by which Queensland offered land cheaply to immigrants who paid their own passage to the colony. Under its provisions, the Agent-General for Emigration could provide assisted passages to emigrants according to the following payment scale: between one and twelve years of age, males $f 2$, females $f 1$; between twelve and forty, males $f 4$, females $f 2$; above forty, of either sex, $f 6$. Persons eligible as assisted passengers were farmers, shepherds, farmers' labourers, vine-dressers, labourers, mechanics and domestic servants. Labourers were further defined as people whose labour had been connected to the land, such as farm servants, gardeners, roadmakers, quarrymen and miners. Mechanics included engineers, enginedrivers, railway carriage builders, carpenters, bricklayers, stonemasons, blacksmiths, wheelwrights and shipbuilders. Each person receiving an assisted passage had to undertake to pay a deposit and then the 
remainder on arrival in Queensland, amounting to $f 16$, being the estimated cost of the passage from England. The Act also included clauses allowing for persons in Queensland to nominate their friends as passengers from England. ${ }^{72}$ Assisted passengers were issued land orders after repayment of their passage money. ${ }^{73}$

To secure emigrants under these provisions, Daintree focused his recruitment activities on more economically depressed areas of Britain where the desired people were most likely to take up the offer of relocating to Queensland. ${ }^{74} \mathrm{He}$ claimed that 'no other emigration service sends more carefully selected Emigrants than our own. ${ }^{75}$ Yet he was aware of recruitment difficulties in the 1870s, explaining in an annual report that other countries, such as Canada, the United States and New Zealand, were also recruiting emigrants from the same areas with greater incentives. ${ }^{76}$ Thus the Agent-General for Canada was working in conjunction with steamship companies to provide not only free passages to emigrants but also free rail travel to ships, something Queensland did not pay for. ${ }^{77}$ Well over a year before reporting this competitive disadvantage for Queensland, Daintree had already indicated the need to pay shipping and railway fares for poor emigrants, but he did not receive a positive response from Brisbane. ${ }^{78}$

Daintree reported the problems involved in recruiting emigrants to the Colonial Secretary. He found it difficult to get many farm labourers or domestic servants from Scotland, for instance, for two reasons. One was that engagements for this type of labourer were made locally for periods of six months at feeing markets in country districts, with only a few days' interval to conclude the arrangement. These contracts were usually agreed through bargaining between masters and men at hiring fairs on fixed dates in market towns. The second was the relative advance in farm labourers' wages in northern Scotland in the second half of the nineteenth century. Thus Daintree found he had to offer too high rates, at around $£ 30$ per year, to first-class labourers in Inverness, Sutherland, Caithness, Ross and other northern Scottish counties to attract emigrants. ${ }^{79}$

Throughout Britain Daintree found there was little chance of obtaining labourers from agricultural districts at assisted rates, for as a class they were (even when well paid) too improvident to save the small sum necessary to emigrate. Miners and mechanics, he found, were more likely to have funds for assisted passages. Daintree thought their exodus would continue as long as the demand in Queensland continued and the rate of wages was maintained while the iron and dependent trades were in a depressed state in Britain. Even though the search for suitable emigrants was hard, Daintree nevertheless had no compunction in turning down unsuitable people. In 1874 he reported that the greater number of applications he received from agricultural labourers were from large families with young children, and it was undesirable to accept their 
applications except in rare cases because they were not in demand in the colony. He also noted that free passages were now rarely granted to married people having young children. ${ }^{80}$

Daintree sometimes received feedback from Queensland that he had allowed undesirable emigrants to seep through the net. In 1875 for example, the Maryborough Chamber of Commerce complained about a number of morally and physically unacceptable immigrants. Daintree's defence was to suggest that these may have been passengers nominated by relatives and friends already in the colony; some of them were probably old and infirm. A certain number of such people were included in each shipment of passengers and the Immigration Act of 1872 gave Daintree no power to prevent them proceeding to Queensland. However, if their relatives and friends had died or did not meet them at the ship's arrival in the colony, they were placed in a local hospital if unfit to work. Referring to emigration from Ireland, he conceded that 'we must condone certain defects inherent to poverty and want of Education, provided muscle and capacity for hard work is secured.' It was impossible for all the Queensland agents in the British Isles to see each individual personally who made an application for an emigration form. However, surgeonsuperintendents employed by the colonial government inspected emigrants on board ship, and were strictly ordered to identify cases of organic disease or passengers ineligible for immigration for medical reasons. ${ }^{81}$

Macalister implicitly criticised Daintree over the relatively small number of unassisted immigrants entering Queensland, a much lower proportion of total immigrants than had been the case a decade earlier. This decline in unassisted emigrants was contrary to Queensland's current immigration policy. Macalister concluded that Daintree was not working hard enough to fill up emigrant ships, and this showed that the Agent-General was not selling Queensland effectively. There was also the suggestion that unsuitable passengers were recruited at the last minute to fill up empty berths. ${ }^{82}$ Daintree defended himself against this accusation by arguing that he sought to reduce the number of unsatisfactory emigrants by arranging, for instance, that his principal agents in the eastern and Midland counties should accompany people to each ship to identify unsuitable passengers. ${ }^{83}$

Daintree did not shy away from reporting difficulties in recruiting emigrants. In 1875 he identified five particular problems affecting the flow of passengers. First, large numbers of people had recently returned from the USA and Canada with bad reports of the state of trade and the dearth of employment in those countries, and this had impinged upon emigration generally. Second, wages had advanced considerably in agricultural districts in the United Kingdom in the last few months and there was no surplus labour in those districts. Good ploughmen now readily obtained 
attractive wages of $£ 40-£ 50$ annually in addition to their board and lodging. In the Midlands and southeastern counties, improving wage rates ranged from 13 to 18 shillings per week for day labour, with higher rates for piece work, and $£ 8-£ 9$ in wages for the harvest month. Third, the constant flow of Irish migration had been interrupted by problems arising from MacDevitt's recruitment activities, referred to above. Fourth, the withdrawal of advances by promissory note for ship-kit and rail fare had influenced the decline in the emigration of agricultural labourers, who were predominantly very poor. Fifth, Queensland's non-acceptance of large families had also affected the number of emigrants. This was the class most desirous of emigrating but only limited demand for such families was evident at Queensland's northern ports. ${ }^{84}$

\section{Shipping arrangements}

At the beginning of his tenure as Agent-General, Daintree complied with the request that he should organise a monthly ship from England and a bimonthly one from the Continent to carry emigrants to Queensland. ${ }^{85}$ However, shipping arrangements were complicated by the the Board of Trade in London insisting that only ships they had surveyed could be used for carrying people according to the imperial Passenger Acts. By 1872 fewer shipping firms were willing to undergo the checks required for them to supply emigrant vessels. ${ }^{86}$ Daintree found the practice of raising tenders for each emigrant voyage to be unsatisfactory. He wanted to negotiate a yearly contract for shippers, renewable at his option, so that he would have time to venture beyond London to give public lectures supporting emigration to Queensland. Cost considerations had to be taken into account. Queensland's northern ports (including Maryborough, Bowen and Rockhampton) involved higher charges for shipping firms than Brisbane because it was almost impossible to secure outward and homeward freights in connection with them. ${ }^{87}$

Daintree advised the Colonial Secretary that tenders for single voyages required complicated coordination between shippers, fitters and provision merchants. It took many months for Queensland's government to acknowledge these problems, but eventually they allowed a one-year contract with Taylor, Bethell \& Roberts of London from July $1873 .{ }^{88}$ This arose after Daintree sought tenders from six British shipping firms with Australian connections. Only two firms offered tenders. Devitt \& Moore called for $£ 165$ shillings per adult for Brisbane and $£ 18$ for the northern ports. Taylor, Bethell \& Roberts wanted $£ 15$ 9s. 6d. per adult for Brisbane and $f 16$ 19s. $6 \mathrm{~d}$. for the northern ports. Daintree accepted the services of the latter, cheaper firm, and confirmed his choice in a telegram to Brisbane. When he did so, he was unaware that his experienced chief clerk, James Wheeler, a one-time temporary Agent-General before Daintree's tenure, had fixed the tender in favour of Taylor, Bethell \& Roberts in return for receiving a generous secret payment from them for 
his own pocket. Daintree looked into the possibility of hiring a steamer to proceed via the Suez Canal and Torres Strait as a trial of that relatively new route, but the rates demanded from any English port were too high to pursue this option. The use of steamers on a significant scale in the Queensland emigration business did not occur until the $1880 \mathrm{~s} .{ }^{89}$

Communications between Daintree and the Colonial Secretary about shipping arrangements, however, did not always proceed smoothly. In 1873 the Queensland government agreed that Daintree could arrange a twelve months' contract with shipping firms rather than calling for single ships, should he deem this the best way of proceeding. Daintree thought this was the most favourable method and, after seeking tenders from various firms, he accepted, as noted above, the services of Taylor, Bethell $\&$ Roberts, operating regular packet ships to various Australian ports under the London Line name. Furthermore, hiring shipping for the future seemed problematic. Not only were the Board of Trade's inspection requirements for ships becoming more onerous, there were many possible outlets throughout the world for shipping firms to offer their services. Taylor, Bethell \& Roberts was the one firm he contacted who were prepared to make arrangements for months ahead; moreover, they employed men who were familiar with the shipping routes to Australia, a matter of no small importance. Daintree had arranged significant reductions in passenger costs with this firm, and argued that it would be impossible to find the requisite tonnage to carry 1,000 passengers per month in the present state of the shipping business if he had to hire individual ships. ${ }^{90}$

Daintree was in a difficult position: shippers complained if he did not provide enough emigrants to fill up their vessels as they lost money for each vacancy, but Queensland's government raised objections when ships were overcrowded and illness broke out among passengers. Daintree tried to resolve this problem by maintaining a reserve quota of emigrants when those who had taken out ship passages failed to take up their places. This was not always a successful strategy, but Daintree continued in this vein until early 1874 when Macalister became Premier and Colonial Secretary after ousting Palmer from office. Macalister wanted to pursue a less expansionist immigration policy than Palmer and one in which costs were reduced and strictly accounted for. ${ }^{91}$ He telegrammed Daintree bluntly stating that he entirely disapproved the 'extension on contract with Taylor Bethell \& Co. Complaints against Vessels are such that tenders ought to have been called for.' This statement referred to irregularities, poor management and reservations about the quality of the immigrants on vessels despatched to Queensland. ${ }^{92}$

This was a serious matter for Daintree because he had relied exclusively on Taylor, Bethell \& Co. to deliver emigrants from the British Isles to Queensland's ports between 1872 and $1875 .{ }^{93}$ In early July 1875 , following 
an advertisement in London's Times newspaper, Daintree received tenders from several London shipping firms, including Taylor, Bethell \& Co., for the emigration service to Queensland. ${ }^{94}$ Soon after the bids were made, fraud was discovered in the London office of this shipping firm. This led to their tender being rejected. Contracts were finally awarded to three other firms - Anderson \& Anderson and Mcllwraith, McEacharn and Company, operating from London, and Thomas Law, based in Glasgow. ${ }^{95}$ Daintree's efforts to secure a regular shipping contract with Taylor, Bethell $\&$ Co. were based on their favourable quotations for the cost of taking passengers to Queensland and on their willingness, alone among the shipping firms he contacted, to offer a regular service to Queensland. He was unaware of the accusations against them that led to the rejection of their services in the summer of 1875.

\section{The Queensland Government Emigration Office}

Daintree's professional London base was the Queensland Government Emigration Office. Assisted by a handful of clerks, he had many administrative duties in the office connected with the recruitment and shipment of emigrants. Problems in the office's bureaucracy led to Daintree's downfall as Agent-General. A supplement to the Queenslander (19 June 1875) included an article entitled 'Immigration Office Scandal.' Evidence of financial mismanagement by the clerical staff in the London office became public in September 1875. Queensland's government decided to probe into the internal workings of the Agent-General's office. The Premier and Colonial Secretary, Macalister, travelled to London to investigate. He found two staff members - the Secretary, James Wheeler, and the Despatching Officer - had received bribes from contractors linked to the provisioning and shipping of emigrants to Queensland. Daintree, unaware of these fraudulent acts, initially defended the two dismissed officers but changed his mind after the misdemeanours were proven. Macalister concluded that Daintree was not at fault for the mismanagement in his office: he was an honourable man who had been duped by his two main clerks. However, Macalister was not pleased to find that Daintree had written letters to the leader of the opposition in Queensland's Legislative Assembly calling for a change of ministry. A few months later, in March 1876, Daintree, who had consumptive problems, resigned his position as Agent-General owing to ill health. ${ }^{96}$

\section{Conclusion}

Daintree's period as Queensland's Agent-General for Emigration between 1872 and 1876 included several positive achievements. He deployed various means to sell Queensland as an emigrant destination through his work at exhibitions in South Kensington where he regularly met visitors. His displays of geological specimens and photographs, arising from his scientific work, were a novel attempt to stimulate emigrant recruitment. He designed posters and published a highly informative book on the 
resources, geography and climate of Queensland, with detailed information on employment opportunities and wages in different lines of agricultural and industrial work. He appears to have enjoyed these aspects of his metropolitan work aiming to promote emigration to Queensland. Daintree also expended much energy in lecturing throughout the provinces mainly in rural districts rather than urban centres. Though he had reservations about the efficacy of lectures in persuading people to migrate to a distant destination, newspaper reports of his lecturing work were positive, noting his ability to engage an audience through natural speaking skills and his agricultural knowledge. He liaised well with subagents provided by the Queensland government for Scotland and Ireland. Net migration to Queensland improved during his incumbency as AgentGeneral. Daintree may have been less enthusiastic in dealing with arrangements with shipping firms for the conveyance of passengers to Queensland, but he skilfully negotiated tenders with the London firm of Taylor, Bethell \& Co. to undertake this business.

Two problems that limited the effectiveness of Daintree's work as AgentGeneral for Emigration were not mainly of his own making. First, he had no knowledge of the fraudulent practices carried out by two colleagues in the Queensland Government Emigration Office, the more senior of whom had worked in that capacity for twelve years. ${ }^{97}$ The nature of the misdemeanours was sufficiently secretive that Daintree was unlikely to know about them, which proved the case, and he cannot really be blamed for their occurrence. They were only revealed after Macalister's comprehensive investigation. Second, changes of premier worked against Daintree. Good relations were maintained between Daintree and Palmer, who were of one accord in wanting to sell Queensland as a colony of opportunity for industrious rural workers and small capitalists wishing to avail themselves of land orders. Palmer's rival Macalister, however, was never on such cordial terms with his Agent-General. He argued that Daintree was failing to attract the right type of emigrant, with insufficient unassisted people opting to sail to Queensland, and that costs were not being kept under check. When Macalister discovered fraud in the Queensland Government Emigration Office, the implication was that administrative procedures there had been neglected. The discovery that Daintree had been in communication with the premier's political rivals in Brisbane was less than welcome. When Daintree resigned his post as Agent-General for Emigration, he was already seriously ill and cooperation with Macalister had broken down, but during his tenure as Agent-General he had promoted emigration positively and successfully in terms of the emigrant flow to Queensland. 
1 G. C. Bolton, 'Daintree, Richard (1832-1878)' in Douglas Pike, ed., Australian Dictionary of Biography: 1851-1890 (hereafter $\underline{\mathrm{ADB}}$ ), iv (Melbourne: Melbourne University Press, 1972), 1-2; A. Mozley, 'Richard Daintree, First Government Geologist of Northern Queensland,' Queensland Heritage, 1/2 (1965), 11-16; G. C. Bolton, Richard Daintree: A Photographic Memoir (Brisbane: Jacaranda Press, 1965); Ian G. Sanker, Queensland in the 1860's: The Photography of Richard Daintree (Fortitude Valley, QLD: Queensland Museum, 1977); Peter Quartermaine, 'International Exhibitions and Emigration: the photographic enterprise of Richard Daintree, Agent-General for Queensland 1872-76,' Journal of Australian Studies, 7/13 (1983), 40-55; Jenny Carew, 'Richard Daintree: Photographs as History,' History of Photography, 23/2 (2015), 157-62.

2 Judith Mackay, Showing Off: Queensland at World Expositions 1862 to 1988 (Brisbane: Central Queensland University Press and Queensland Museum, 2004), 21.

3 Wayne O'Donohue, 'First Agents-General: Development of the Office in London, 1860-1876,' Journal of the Royal Historical Society of Queensland (hereafter JRHSQ), 11/3 (1982), 67; Bolton, 'Daintree, Richard,' 1-2. For an illustration of the Queensland Annexe, see 'The Queensland Annexe at the London International Exhibition,' Australasian Sketcher, 15 Apr. 1873, 8.

4 Barbara R. Penny, 'Establishing a nineteenth-century government office, the Australian Agencies General,' Public Administration, XXII/2 (1963), 178-98 (quotation on 178).

5 Joanne Scott, Ross Laurie, Bronwyn Stevens and Patrick Weller, The Engine Room of Government: The Queensland Premier's Department 1859-1901 (St Lucia: University of Queensland Press, 2001), 58; Bolton, Richard Daintree, 23-4.

6 Report from the Agent-General for Emigration for the Year 1872, Votes and Proceedings of the Queensland Parliament (hereafter QVP) (1873), 997. For further details of the act, see 'The Queensland Immigration Act of 1872,' Evening News (Sydney), 14 Feb. 1873, 3.

7 This is shown in the histograms presented in J.C.R. Camm, 'The Origins of Assisted British Migrants to Queensland 1871-1892,' Australian Geographical Studies, 23 (1985), fig. 1, 89. 8 This is shown in the line graph presented in ibid., fig. 2, 91. For annual figures on immigration to colonial Queensland, see Helen R. Woolcock, 'Healthcare on Queensland Immigrant Vessels 18601900' (University of London PhD, 1983), table 4, 527.

9 Raymond Evans, A History of Queensland (Cambridge: Cambridge University Press, 2007), 85; Bill Thorpe, Colonial Queensland: Perspectives on a Frontier Society (St Lucia: University of Queensland Press, 1996), 125.

10 Camm, 'The Origins of Assisted British Migrants,' 88.

11 B. R. Penny, 'Establishing a Nineteenth Century Government Office: The Australian AgenciesGeneral,' Public Administration, 22/2 (1963), 178-98; M. J. Ryman, 'Genesis of a Colonial Secretary's Office: The Queensland Colonial Secretary's Office and its Records, 1859-1898,' Archives and Manuscripts, 4/2 (1970), 17-30; O'Donohue, 'First Agents-General,' 59-74.

12 W. Ross Johnston, 'The Selling of Queensland: Henry Jordan and Welsh Emigration,' $\mathrm{LRHSQ}$, 14/10 (1992), 379-92; Jennifer Harrison, 'My Mission in Ireland: Henry Jordan and Queensland Immigration,' Queensland History Journal, 23/3 (2016), 158-74; Jeremy Hodes, 'John Douglas, Agent-General for Emigration to Queensland, 1869-1871,' JRHSQ, 17/12 (2001), 529-44.

13 For previous considerations of Daintree's emigration work, see O'Donohue, 'First AgentsGeneral,' 67-70; Clem Lack, 'Colonial Representation in the Nineteenth Century. Part II. Some Queensland and other Australian Agents-General,' JRHSQ, 8/1 (1966), 89-92; and Bolton, Richard Daintree, 26-39.

14 Bolton, Richard Daintree, 24.

15 Mitchell Library, State Library of New South Wales, Sydney (hereafter ML), Daintree to William Branwhite Clarke, 16 Mar. 1872, William Branwhite Clarke Papers, MS 139/36x.

16 Queensland State Archives, Runcorn, (hereafter QSA), Colonial Secretary (hereafter CS) to Daintree, 1 Mar. 1875, Agent-General for Queensland: Indexes to letterbooks, series ID 11934 item ID 6896.

17 Mackay, Showing Off, 22.

18 Mozley, 'Richard Daintree,' 14. Appreciative reviews of the exhibits, praising Daintree's enterprise, appeared in the London Evening Standard, 9 June 1873, 4, and the London Graphic, 11 Oct. 1873.

19 O'Donohue, 'First Agents-General,' 68; Bolton, Richard Daintree, 25; 'Report from the AgentGeneral,' Rockhampton Bulletin, 31 July 1873, 2.

20 Mackay, Showing Off, 24.

21 lbid., 23. 
22 Gael Newton, Shades of Light: Photography and Australia, 1839-1988 (Canberra: Australia National Gallery, 1988), 46-8.

23 Bolton, Richard Daintree, 24; Daintree to the Minister for Works, 17 Mar. 1872, QVP (1872), 1500 (quotation).

24 Sanker, Queensland in the 1860's, 70.

25 O'Donohue, 'First Agents-General,' 67-8; RIchard Daintree, Queensland, Australia: its territory, climate and products, agricultural, pastoral and mineral etc., with emigration regulations:

illustrated with maps and plates (London: Street, 1873)..

26 Daintree, Queensland, 92.

27 E.g. Hampshire Advertiser (Southampton), 29 Mar. 1873, 1; Central Somerset Gazette

(Glastonbury), 6 Apr. 1872, 1; Western Gazette (Yeovil), 12 Mar. 1875, 6; 'Free Emigration to

Queensland,' Belfast News-Letter, 25 Nov. 1876, 1.

28 E.g. London Evening Standard, 27 Feb. 1872, 1.

29 Shields Daily News, 17 Mar. 1876, 1.

30 'Queensland,' Glasgow Herald, 29 Oct. 1872, 2; 'Emigration,' Worcestershire Chronicle, 24 July 1875, 7; 'Emigration,' Supplement to the Norfolk Chronicle and Norwich Gazette, 24 July 1875, 10. $31 \mathrm{ML}$, Daintree to Clarke, 18 Mar. 1873, William Branwhite Clarke Papers.

32 QSA, Annual Report of the Agent-General for Emigration, Queensland, 1874, Despatches written by the Agent-General, London, series ID 5321 item ID 860786.

33 'Our Agent-General for Emigration,' Brisbane Courier (hereafter BC), 23 Dec. 1872, 2.

34 Daintree to the CS, 4 Sept. 1874, QVP (1875), 628.

35 'Mr Wight in Scotland,' Week (Brisbane), 15 Jan. 1876, 2.

36 ML, Daintree to Clarke, 18 Mar. 1873, William Branwhite Clarke Papers.

37 QSA, Annual Report of the Agent-General for Emigration, Queensland, 1874, Despatches written by the Agent-General, London, series ID 5321 item ID 860786.

38 O'Donohue, 'First Agents-General,' 67.

$39 \mathrm{ML}$, Daintree to Clarke, 29 July 1872, William Branwhite Clarke Papers.

40 QSA, Daintree to the CS, 15 Apr. 1874, Despatches written by the Agent-General, London, series ID 5321 item ID 860783.

41 Daintree to the CS, 8 June 1874, QVP (1875), 625.

42 Rosemary Lawson, 'Immigration into Queensland, 1870-1890' (University of Queensland B.A., 1963), 48.

43 Pamela Horn, 'Agricultural Trade Unionism and Emigration, 1872-1881,' The Historical Journal, XV/1 (1972), 87-102.

$44 \mathrm{ML}$, Daintree to Clarke, 18 Mar. 1873, William Branwhite Clarke Papers.

45 'Mr Daintree at Work,' Queenslander, 30 Nov. 1872, 3. For similar details about lectures given by Daintree in Glasgow, 22 October 1872, Aylesbury, 14 Dec. 1872, and Blandford, 21 Sept. 1872, see 'Our Agent-General for Emigration,' BC, 23 Dec. 1872, 2; Bucks Herald (Aylesbury), 21 Dec.

1872, 6; and 'Free Emigration,' Grantham Journal, 28 Sept. 1872, 7.

46 Guy Featherstone, 'Bonwick, James (1817-1906)' in Pike, ed., ADB, iii, ?

47 QSA, Annual Report of the Agent-General for Emigration, Queensland, 1874, Despatches

written by the Agent-General, London, series ID 5321 item ID 860786.

48 Daintree to the CS, 26 June 1874, QVP (1875), 631.

49 James Bonwick to Daintree, 1 Aug. 1874, ibid. (1875), 632-3.

50 QSA, CS to Daintree, 2 Nov. 1874, Agent-General for Queensland: Indexes to letterbooks of letters to the Agent-General in London, series ID 11934 item ID 6896.

51 Daintree to the CS, 6 Jan. 1875, QVP (1875), 634. It is worth noting that Bonwick was reappointed to a similar position by the Queensland government in 1882-3: see Featherstone, 'Bonwick,' ?

52 CS to the Agent-General, 27 June 1874, QVP (1875), 627.

53 Under CS to the Agent-General, 8 Dec. 1874, and Copy of Minute of Proceedings of the Executive Council on 18 Nov. 1874, ibid. (1875), 597.

54 Under CS to Daintree, 21 July 1874, ibid. (1875), 630.

55 QSA, Daintree to the CS, 4 Mar. 1875, Agent-General letterbooks, series ID 10742 item ID 40.

56 The Under CS to Mr E. O'D. MacDevitt and to George Wight, 8 Dec. 1874, QVP (1875), 598.

Wight had a detailed knowledge of Queensland, and was the author of Queensland, the Field for

British Labour and Enterprise and the Source of England's Cotton Supply, $2^{\text {nd }}$ edn. (London: Street, 1862). 
57 H. J. Gibbney, 'MacDevitt, Edward O'Donnell (1845-1898)' in Bede Nairn, Geoffrey Serle and Russel Ward, eds., ADB (Melbourne: Melbourne University Press, 1974), v, 144; Anne McLay, James Quinn: First Catholic Bishop of Brisbane (Toowoomba, QLD: Church Archivists' Society, 1989), 179. 58 G. L. Lockley, 'Wight, George (1817-1900)' in Geoffrey Serle and Russel Ward, eds., ADB (Melbourne: Melbourne University Press, 1976), vi, 398; Denis Cryle, The Press in Colonial Queensland 1845-1875 (St Lucia: University of Queensland Press, 1989), 72.

59 Under CS to the CS, 30 Mar. 1875, QVP (1875), 599.

60 QSA, Daintree to the CS, 15 Apr. 1874, Despatches written by the Agent-General, London, series ID 5321 item ID 860783.

61 Daintree to the CS, 2 Oct. 1874, QVP (1875), 631.

62 Agent-General to the CS, 4 Mar. 1875, ibid., 599.

63 QSA, Daintree to the CS, 29 Jan. 1875 and Thomas Smith to Daintree, 26 Nov. 1874, Despatches written by the Agent-General, London, series ID 5321 item ID 860785.

64 Lockley, 'Wight, George,' 398. See also 'Mr Wight at Home,' Maryborough Chronicle, Wide Bay and Burnett Advertiser, 26 June 1875, 3.

65 QSA, Wight to Daintree, 15 June 1875, Despatches written by the Agent-General, London, series ID 5321 item ID 860786. Another agent, based in Elgin, agreed with this conclusion: see Daintree to the CS, 10 Dec. 1874, OVP (1875), 643.

66 'Scotch Emigration (First Annual Report - From March, 1875, to March, 1876,') QVP (1876), 1057-8.

67 'The Scottish Emigration Agent,' BC, 21 June 1875, 3; 'Lecture on Queensland,' Forres Elgin \& Nairn Gazette, Northern Review and Advertiser (Forres), 3 Nov. 1875, 2; 'Queensland as a Field for Emigration,' Edinburgh Evening News, 30 Apr. 1875, 2.

68 'Queensland as a Field for Emigration,' Portadown News, 5 June 1875, 3; Irish Times, 22 Dec. $1875,5$.

69 Daintree to Arthur Macalister, 5 Aug. 1875, QVP (1876), ?.

70 Daintree to the CS, 30 Dec. 1875, and Daintree to P. H. Nind, 19 Dec. 1875, ibid. (1876), 1061. 71 QSA, Nind to Daintree, 3 Mar. 1876, Despatches written by the Agent-General, London, series ID 5321 item ID 860787.

72 'The Immigration Bill of 1872,' Rockhampton Bulletin, 27 July 1872, 4.

73 Robin F. Haines, Nineteenth-Century Government Assisted Immigrants from the United Kingdom to Australia: Schemes, Regulations and Arrivals 1831-1900 and Some Vital Statistics 1834-60,

Flinders University Occasional Papers in Economic History no. 3 (1995), 28.

74 O'Donohue, 'First Agents-General,' 68.

75 QSA, Daintree to the CS, 15 Apr. 1874, Despatches written by the Agent-General, London, series ID 5321 item ID 860783.

76 Report from the Agent-General for Emigration for this year 1872, QVP (1873), 997-1000.

77 QSA, Annual report of the Agent-General for Emigration, Queensland, 1874, Despatches written by the Agent-General, London, series ID 5321 item ID 860786.

78 QSA, Daintree to the CS, 2 Jan. 1873, Despatches written by the Agent-General, London, series ID 5321 item ID 860782.

79 QSA, Daintree to the CS, 29 Jan. 1875, Despatches written by the Agent-General, London, series ID 5321 item ID 860785; J.P.D. Dunbabin, Rural Discontent in Nineteenth-Century Britain (London: Faber and Faber, 1974), 130-1. Data and analysis on rising agricultural labourers' wages in late $19^{\text {th }}$-century Scotland can be found in E. H. Hunt, 'Industrialization and Regional Inequality: Wages in Britain, 1760-1914, Journal of Economic History, 46/4 (1986), 946, 966.

80 QSA, Annual Report of the Agent-General for Emigration, Queensland, 1874, Despatches written by the Agent-General, London, series ID 5321 item ID 860786. Daintree's comments on the metal industries reflected the heavy unemployment in that sector of the British economy in 1873: see A. E. Musson, 'The Great Depression in Britain, 1873-1896,' Journal of Economic History, 19/2 (1959), 202.

81 QSA, Daintree to the CS, 16 Apr. 1875, Despatches written by the Agent-General, London, series ID 5321 item ID 860785.

82 Bolton, Richard Daintree, 35.

83 Daintree to the CS, 8 June 1874, QVP (1875), 625.

84 QSA, Daintree to Macalister, 5 Aug. 1875, Despatches written by the Agent-General, London, series ID 5321 item ID 860786.

85 Daintree to the CS, 16 Apr. 1873, QVP (1873), 997. 
86 Helen R. Woolcock, Rights of Passage: Emigration to Australia in the Nineteenth Century (London: Tavistock Publications, 1986), 72.

87 Daintree to the CS, 16 Apr. 1873, QVP, 997.

88 Woolcock, Rights of Passage, 72.

89 lbid., 72, 349.

90 Daintree to the CS, 20 Mar. 1874, QVP, 611.

91 Bolton, Richard Daintree, 32-3.

92 Daintree to the CS, 20 Mar. 1874, QVP, 611; Bolton, Richard Daintree, 31.

93 Woolcock, Rights of Passage, 73.

94 These are printed in QVP, 1875, 583-7.

95 Woolcock, Rights of Passage, 73, 336.

96 O'Donohue, 'First Agents-General,' 69-70; Lack, 'Colonial Representation,' 90-2; Bolton, Richard Daintree, 39.

97 Bolton, Richard Daintree, 34. 